\title{
Non-parallelism of islet amyloid polypeptide (amylin) and insulin gene expression in rat islets following dexamethasone treatment
}

\author{
H. Mulder ${ }^{1}$, B. Ahrén ${ }^{2}$, M. Stridsberg ${ }^{3}$, F. Sundler ${ }^{1}$ \\ ${ }^{1}$ Department of Medical Cell Research, University of Lund, Sweden \\ ${ }^{2}$ Department of Medicine, Malmö General Hospital, University of Lund, Sweden \\ ${ }^{3}$ Department of Clinical Chemistry, University Hospital, Uppsala, Sweden
}

Summary Islet amyloid polypeptide (IAPP), a novel islet hormone candidate, has been reported to be over-expressed relative to insulin in rats following dexamethasone treatment. In order to investigate the expression of IAPP and insulin following dexamethasone treatment of rats for 12 days, we applied in situ hybridization and immunocytochemistry, allowing us to evaluate islet changes in gene expression and morphology. Tissue concentrations of IAPP and insulin were measured by radioimmunoassay. A low dose of dexamethasone $(0.2 \mathrm{mg} / \mathrm{kg}$ daily) increased the islet levels of IAPP and insulin mRNA to $249 \pm 13 \%$ and $150 \pm 24 \%$ of controls, respectively $(p<0.001$ and $p<0.01)$. A high dose of dexamethasone $(2.0 \mathrm{mg} / \mathrm{kg}$ daily) increased the islet levels of IAPP and insulin mRNA to $490 \pm 13 \%$ and $203 \pm 9 \%$ of controls, respectively $(p<0.001$ and $p<0.001)$. The pancreatic concentration of IAPP increased more than that of insulin $(p<0.05)$. Morphometric analysis revealed that dexamethasone treat- ment induced both hyperplasia and hypertrophy of insulin cells. Changes in the cellular localization of IAPP and insulin mRNA were not observed. Thus, we conclude that the increased level of IAPP mRNA is due to both an increase at the cellular level as well as hyperplasia/hypertrophy of insulin cells. In contrast, the increased level of insulin mRNA appears to be due to hyperplasia/hypertrophy of insulin cells, since insulin gene expression decreased at the cellular level ( $p<0.001$ vs controls). These observations provide further evidence that IAPP and insulin gene expression are regulated in a non-parallel fashion, which may be relevant to the pathogenesis of non-insulin-dependent diabetes mellitus [Diabetologia (1995) 38: 395-402]

Key words Islet amyloid polypeptide, amylin, insulin, dexamethasone, rat, pancreatic islets, in situ hybridization, gene expression, mRNA.
Islet amyloid polypeptide (IAPP), or amylin, is a putative peptide hormone, bearing a structural resemblance to calcitonin gene related peptide (CGRP) [1, 2]. The polypeptide, which is predominantly expressed in insulin cells [3], is the main constituent of islet amyloid formed in patients with non-insulin-de-

Received: 13 July 1994 and in revised form: 4 October 1994

Corresponding author: Dr. H. Mulder, Department of Medical Cell Research, University of Lund, Biskopsgatan 5, Lund, S22362 Sweden

Abbreviations: IAPP, islet amyloid polypeptide; NIDDM, noninsulin-dependent diabetes mellitus; ISH, in situ hybridization; SSC, saline sodium citrate; CGRP, calcitonin gene related peptide pendent diabetes mellitus (NIDDM) and insulinoma $[1,2,4]$. The physiological role of IAPP has remained unresolved [5], although restraining effects on insulin actions in skeletal muscle [6,7] and liver [8] as well as inhibitory effects on insulin secretion from islets [9] and pancreas [10] have been observed. The insulin restraining effects of IAPP in conjunction with its amyloidogenic properties have caused considerable interest, focussing on a possible role in the pathogenesis of NIDDM.

If IAPP is a pathogenetic factor in NIDDM, an over-expression of IAPP at some point in these events could contribute to the development of the disease. In fact, following dexamethasone treatment of rats which is known to induce insulin resistance, 
the ratio of IAPP/insulin expression is increased, since both the level of IAPP mRNA [11] and IAPPsecretion [12] are increased more than that of insulin. Furthermore, an increased ratio of IAPP/insulin expression was recently shown to be a feature of insulin resistance when hyperglycaemia is prevalent [13]. The available data on insulin and IAPP gene expression following dexamethasone treatment, however, apply only to the effects in the entire pancreas. In view of the islet growth-promoting action of glucocorticoids $[14,15]$ as well as the dual localization of IAPP expression in insulin and somatostatin cells $[16,17]$, we have further studied the mechanisms underlying the increased ratio of IAPP/insulin gene expression. For this purpose we used in situ hybridization (ISH) and immunocytochemistry, enabling us to evaluate the effects of dexamethasone treatment at the cellular level. Further, these results were correlated to the tissue concentration of IAPP and insulin.

\section{Materials and methods}

Experimental animals and tissue processing. Twenty-four male Sprague-Dawley rats were randomly divided into three groups of eight rats. The rats in the first and second groups were injected daily with $2.6 \mathrm{mg} / \mathrm{kg}$ and $0.26 \mathrm{mg} / \mathrm{kg}$ dexamethasone phosphate (Sigma, St. Louis, Mo., USA) intraperitoneally, while the control group received an equal volume of saline $(1.3 \mathrm{mg}$ dexamethasone phosphate is equivalent to $1.0 \mathrm{mg}$ dexamethasone). The rats were injected daily for 12 days, fasted overnight and killed by exposure to diethylether, after which specimens from the pancreas were promptly excised.

For ISH and combined ISH and immunocytochemistry (immunoperoxidase), the specimens were fixed in buffered $4 \%$ paraformaldehyde ( $\mathrm{pH} 7.2$ ). All specimens for quantitative ISH were collected at the same time, using the same batch of freshly made paraformaldehyde and fixed for $22 \mathrm{~h}$. They were then dehydrated and embedded in paraffin. Sections were cut to 4- $\mu \mathrm{m}$ thickness in a microtome and mounted on chrome-alum coated slides. For immunofluorescence, the specimens were immersed overnight in Stefanini's fixative (2\% paraformaldehyde and $0.2 \%$ picric acid in phosphate buffer, $\mathrm{pH} 7.2$ ), rinsed repeatedly in Tyrode solution enriched with sucrose $(10 \%)$ and frozen on dry ice. The specimens were stored at $-80^{\circ} \mathrm{C}$ until being cut to $10 \mu \mathrm{m}$ thickness in a cryostat, mounted on slides and further processed for immunocytochemistry as described below.

In situ hybridization (ISH). For ISH a 30-mer oligodeoxyribonucleotide homologous to IAPP cDNA 169-198 [18], having only a $20 \%$ homology with $\alpha$-CGRP cDNA [19], was used. For detection of insulin mRNA, a probe mix, consisting of six 30-mer oligodeoxyribonucleotides was used (BPR 236; R\&D Systems, Abingdon, UK). The insulin probes were complementary to the regions in rat insulin gene I and II that were the most homologous [20], with a maximum of three mismatches, ensuring equal labelling of both insulin gene transcripts. The probes were 3 '-endtailed with ${ }^{35} \mathrm{~S}$-dATP by use of terminal transferase (both supplied by NEN duPont, Stockholm, Sweden), yielding a specific activity of approximately $2 \times 10^{9} \mathrm{cpm} / \mu \mathrm{g}$. After labelling, the probes were purified using
Chroma Spin-10 columns (Clontech - Intermedica, Stockholm, Sweden).

The hybridization protocol used has previously been described in detail [17]. Briefly, the sections were deparaffinized, rehydrated and permeabilized in $0.25 \%$ Triton X-100. Prior to hybridization the sections were digested by proteinase K (10 $\mu$ l, Sigma Chemical Company, St. Louis, MO, USA) and acetylated by $0.25 \%$ acetic anhydride in $0.1 \mathrm{~mol} / \mathrm{l}$ ethanolamine. Hybridization was carried out overnight at $37^{\circ} \mathrm{C}$ in sealed moisturizing chambers, using probe concentrations of $600 \mathrm{fmol} / \mathrm{ml}$ and $200 \mathrm{fmol} / \mathrm{ml}$ for the IAPP and insulin probes, respectively. After hybridization, the sections were washed in $0.5 \times \mathrm{SSC}$ (saline sodium citrate; $1 \times \mathrm{SSC}=0.15 \mathrm{~mol} / 1$ $\mathrm{NaCl}, 0.015 \mathrm{~mol} / \mathrm{l}$ sodiumcitrate; $4 \times 15 \mathrm{~min}, 55^{\circ} \mathrm{C}$ ) followed by once in $1 \times \mathrm{SSC}$ ( $30 \mathrm{~min}$, room temperature). The slides were dipped in Ilford K-5 emulsion, exposed for 4 (insulin) or 10 (IAPP) days and developed in Kodak D-19.

For control purposes, hybridization was also performed after incubation in RNase A $(45 \mu \mathrm{g} / \mathrm{ml}$, Sigma; $30 \mathrm{~min}$ at $37 \mathrm{C}$ ) or in the presence of a 100 -fold molar excess of unlabelled probe in the hybridization buffer. Also, a non-complementary 30-mer oligodeoxyribonucleotide (5'-TCGT-TGTTGGAACCAGGTCAGGAGGGTGGT-3') was used for the control experiments [17]. In the control experiments, autoradiographic labelling of the islets was not obtained.

The combination of ISH and immunocytochemistry was used to define the cellular localization of IAPP and insulin mRNA in islets from rats treated with dexamethasone $2.0 \mathrm{mg} /$ $\mathrm{kg}$ and their controls and was performed as previously described [17]. Briefly, hybridization was performed as above. After the post-hybridization washes, the slides were processed for immunoperoxidase. The sections were incubated overnight with primary antibodies against IAPP (1:1280; 9056, Euro-Diagnostica, Malmö, Sweden), proinsulin (1:2560; 9003 , Euro-Diagnostica), somatostatin (1:800; IncStar Corp., Stillwater, Minn., USA), glucagon (1:5180; Euro-Diagnostica) or pancreatic polypeptide (1:1280; Dr. R.Chance, Eli Lilly \& Co, Minneapolis, Minn., USA). An unlabelled secondary antibody (anti-rabbit or anti-guinea pig IgG, 1:80) was applied followed by a peroxidase-anti-peroxidase complex (1:160, all from DAKO, Copenhagen, Denmark). The site of the peroxidase, revealing the localization of the antigen-antibody reaction, was visualized by exposure to diaminobenzidine tetrahydrochloride (Sigma). After rinsing in distilled water for $10 \mathrm{~min}$, the sections were processed for autoradiography as described above. The antibodies used in our experiments have previously been tested for specificity and crossreactivity [17], with the exception of 9056 . This antibody did not demonstrate CGRP, using paraffin embedded tissue; the immunoreactivity was quenched by preabsorption of the antibodies with ratIAPP $(100 \mu \mathrm{g} / \mathrm{ml}$ in antibody solution at working dilution).

Quantification of in situ hybridization. For the quantification of autoradiographic probe-labelling in islets, an interactive computerized image analysis system (IBAS - Kontron; Zeiss, Oberkochen, Germany) was used. The sections were viewed in darkfield through a $20 \times$ objective in an Axioplan microscope (Zeiss) connected to an MTI videocamera, generating a digitized image of $512 \times 512$ pixels; the polarity of the image was reversed and a threshhold set at grey level 60 . A program was created to determine the area of the grains covering an islet as well as the total area of the cells labelled by the probes. In this way underestimation of grain number, due to clustering of grains, was circumvented. Data are presented as (i) the mean area of grains covering islets and (ii) the mean of the area of grains divided by the area of labelled cells. This enabled us to estimate gene expression as (i) the islet level of 
Table 1. Quantitative in situ hybridization with radiolabelled IAPP and insulin oligoprobes in pancreatic sections from rats treated with dexamethasone

\begin{tabular}{|c|c|c|c|c|}
\hline & \multicolumn{2}{|l|}{ IAPP } & \multicolumn{2}{|l|}{ Insulin } \\
\hline & $\begin{array}{l}\text { Islet gene } \\
\text { expression }\end{array}$ & $\begin{array}{l}\text { Cellular gene } \\
\text { expression }\end{array}$ & $\begin{array}{l}\text { Islet gene } \\
\text { expression }\end{array}$ & $\begin{array}{l}\text { Cellular gene } \\
\text { expression }\end{array}$ \\
\hline $\begin{array}{l}\text { Low dose dexamethasone } \\
(0.2 \mathrm{mg} / \mathrm{kg})\end{array}$ & $\begin{array}{r}7446 \pm 1005^{b} \\
(249 \pm 13 \%)\end{array}$ & $\begin{array}{l}20.1 \pm 1.8 \% \\
(107 \pm 9 \%)\end{array}$ & $\begin{array}{r}8349 \pm 2017^{a} \\
(150 \pm 24 \%)\end{array}$ & $\begin{array}{c}27.7 \pm 4.2 \% \mathrm{~b} \\
(59 \pm 15 \%)\end{array}$ \\
\hline $\begin{array}{l}\text { High dose dexamethasone } \\
(2.0 \mathrm{mg} / \mathrm{kg})\end{array}$ & $\begin{array}{r}14622 \pm 1871^{b} \\
(490 \pm 13 \%)\end{array}$ & $\begin{array}{l}27.8 \pm 1.7 \%{ }^{b} \\
(148 \pm 6 \%)\end{array}$ & $\begin{array}{r}11253 \pm 975^{b} \\
(203 \pm 9 \%)\end{array}$ & $\begin{array}{c}26.0 \pm 2.2 \% \%^{b} \\
(55 \pm 8 \%)\end{array}$ \\
\hline
\end{tabular}

The levels of IAPP and insulin mRNA were quantitated by an estimation of the area $\left(\mu \mathrm{m}^{2}\right)$ of the autoradiographic grains covering an islet using an interactive computerized image analysis system. Cellular levels of IAPP and insulin mRNA were calculated by dividing the area of grains by the area of the la-

the respective mRNA as well as (ii) the unit area level of mRNA reflecting the cellular level of the respective mRNA. Thus, changes in the mRNA levels for the respective probes were quantitated $\left(\mu \mathrm{m}^{2}\right)$ and the relative changes for the levels of IAPP and insulin mRNA were compared.

All sections were hybridized to the respective probe(s) in the same experiment and thus analysed under identical conditions. They were analysed in duplicate, determining grain and cell areas in eight randomly-selected islets from different parts of the sections. An extra set of slides was processed identically and used for assessment of the correct exposure time, in order to avoid saturation of the autoradiographic emulsion and loss of its linear response to the radiolabelled probes. That the respective $\mathrm{mRNA}$ levels were quantitated in the same range of the response curve of the emulsion was ensured by the grain areas being of the same magnitude.

Plasma glucose and radioimmunoassays. Prior to killing, the anaesthetized animals were subjected to a retro-bulbar blood sampling for measurement of plasma glucose levels, using the glucose oxidase technique. After killing, samples of pancreatic tissue were extracted in acid ethanol for determination of tissue concentrations of IAPP and insulin. The peptide concentrations were determined by the use of radioimmunoassays (RIA). In brief, the insulin levels were determined by the use of a guinea pig anti-porcine insulin antibody (Linco, St. Louis, Mo., USA) with ${ }^{125}$ I-labelled porcine insulin as tracer and rat insulin (Novo Nordisk Laboratories., Bagsvaerd, Denmark) as standard; the free and bound radioactivity were separated using a double antibody technique [21]. IAPP was measured by a competitive RIA as previously described [22]. In brief, this assay employed a polyclonal rabbit antiserum against human IAPP (Peninsula Laboratories, Belmont, Calif., USA), with complete cross-reaction to rat IAPP, but lacking cross-reaction with $\alpha$-calcitonin gene-related peptide. Standard was prepared from human IAPP (Peninsula Laboratories) and tracer was prepared by labelling the peptide with ${ }^{125} \mathrm{I}$ (Amersham International, Amersham, Bucks., UK). Separation of free and antibodybound radioactivity was achieved by means of a second antirabbit antibody coupled to a solid phase (Pharmacia, Uppsala, Sweden).

Immunocytochemistry. For evaluation of the effects of dexamethasone on cell number, insulin cells were identified in cryostat sections with a proinsulin antibody $(1: 1280 ; 9003)$ using the method of indirect immunofluorescence as previously described [17]. An insulin cell was defined as a nucleated immunoreactive cell. The numbers of insulin cells in 53 islets from belled cells. All results given as mean \pm SEM; percentage of controls within parentheses. The grain areas of treated rats and their controls, respectively, were compared using Kruskal-Wallis' test (two-tailed) and Dunn's test for multiple comparisons post hoc. ${ }^{\mathrm{a}} p<0.01 ;{ }^{\mathrm{b}} p<0.001$ (vs controls)

six rats injected with dexamethasone $2.0 \mathrm{mg} / \mathrm{kg}$ and in 55 islets from six control rats were determined.

\section{Statistical analysis}

All data are presented as mean \pm SEM. Statistical evaluation of the data was performed with the two-tailed Kruskal-Wallis test for comparing grain areas and areas of labelled cells from treated animals for quantification of ISH. Multiple comparisons post hoc were performed using Dunn's Test. The Student's t-test was used to evaluate radioimmuno assays. The Mann-Whitney U-test was used to compare immunocytochemistry data.

\section{Results}

Plasma glucose. Plasma glucose levels were slightly elevated in rats treated with the high dose of dexamethasone $(8.6 \pm 0.8 \mathrm{mmol} / \mathrm{l} ; p<0.05)$, as compared to the control group $(6.6 \pm 0.4 \mathrm{mmol} / \mathrm{l})$, whereas the plasma glucose levels in the rats treated with the low dose of dexamethasone were not significantly different from controls $(7.4 \pm 0.4 \mathrm{mmol} / \mathrm{l})$.

Gene expression of the peptides. The data are summarized in Table 1. At the low dose of dexamethasone $(0.2 \mathrm{mg} / \mathrm{kg})$, the islet level of IAPP mRNA was increased to $249 \pm 13 \%$ of controls $(p<0.001)$, whereas the cellular level of IAPP mRNA was not affected. Furthermore, at the high dose of dexamethasone $(2.0 \mathrm{mg} / \mathrm{kg})$, the islet level of IAPP mRNA was increased to $490 \pm 13 \%$ of controls $(p<0.001)$, while the cellular level of IAPP mRNA was increased to $148 \pm 6 \%$ of controls ( $p<0.001$; Fig. $1 \mathrm{~A}, \mathrm{C}, \mathrm{E})$.

The low and high doses of dexamethasone increased the islet levels of insulin mRNA to $150 \pm 24 \%$ and $203 \pm 9 \%$ of controls, respectively $(p<0.01$ and $p<0.001)$. In contrast, the cellular level of insulin mRNA was equivalently reduced to $59 \pm 15 \%$ and $55 \pm 8 \%$ of controls at the low and 

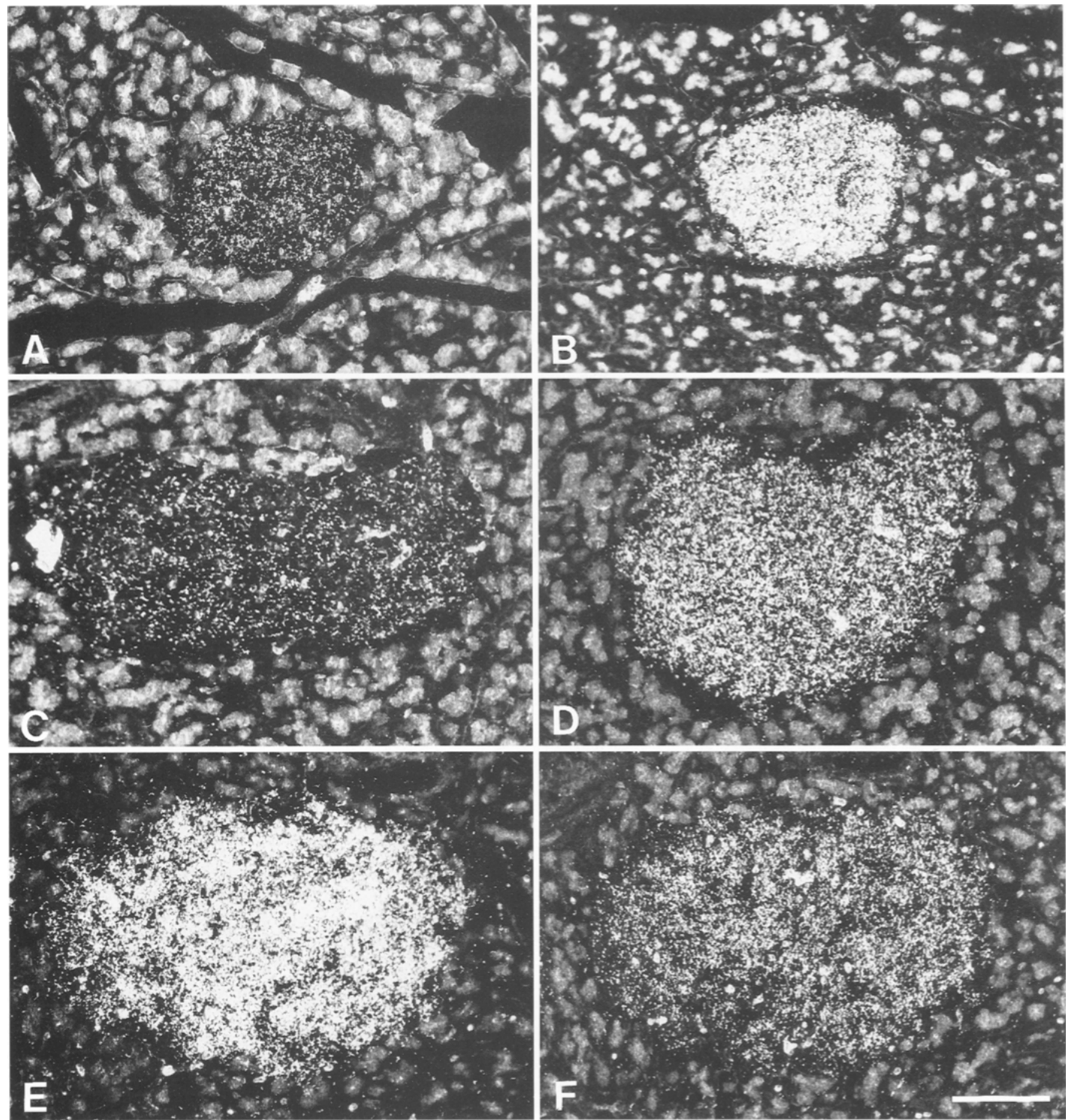

Fig. 1A-F. Islets from control rats $(\mathbf{A}, \mathbf{B})$ and rats treated with dexamethasone $0.2 \mathrm{mg} / \mathrm{kg}(\mathbf{C}, \mathbf{D})$ and $2.0 \mathrm{mg} / \mathrm{kg}(\mathbf{E}, \mathbf{F})$ hybrid ized with an IAPP probe $(\mathbf{A}, \mathbf{C}, \mathbf{E})$ or insulin probes $(\mathbf{B}, \mathbf{D}, \mathbf{F})$. The sections are viewed in darkfield. The density of auto radiographic labelling with the IAPP probe is the same in controls $(\mathbf{A})$ and at the low dose of dexamethasone $(\mathbf{C})$ but is increased at the high dose of dexamethasone (E), indicating an increase in the level of IAPP mRNA in the insulin cells at the high dose of dexamethasone. However, the total area of

grains is increased even at the low dose of dexamethasone (C), reflecting hyperplasia/hypertrophy of insulin cells. With the insulin probes, a decreased density of autoradiographic labelling is seen at both doses of dexamethasone $(\mathbf{D}, \mathbf{F})$ as compared to controls (B), although the total area of grains in the islets is increased, due to hyperplasia/hypertrophy of insulin cells. Note that islets in $\mathbf{A}$ and $\mathbf{B}$ as well as in $\mathrm{E}$ and $\mathbf{F}$ are identical (adjacent sections); islets in $\mathbf{C}$ and $\mathbf{D}$ are from the same rat. $\mathrm{Bar}=100 \mu \mathrm{m}$ 


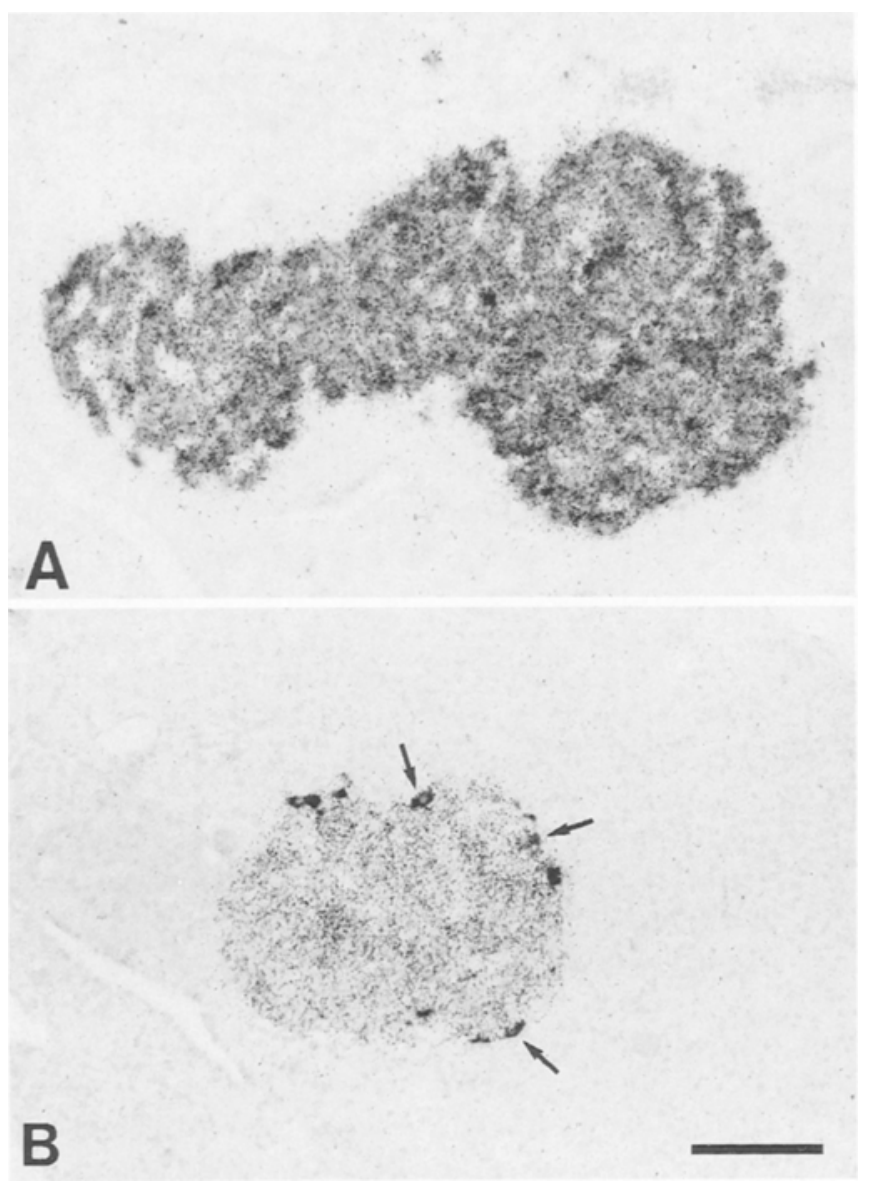

Fig. 2A, B. Islets from rats treated with dexamethasone 2.0 $\mathrm{mg} / \mathrm{kg}$; sections hybridized with an IAPP probe followed by immunocytochemical detection (immunoperoxidase) of islet hormones. Immunostaining for LAPP (A) reveals that all cells containing IAPP mRNA also store IAPP. Note the enlargement and irregularity of the islet, typical of glucocorticoid treatment. (B) Immunostaining for somatostatin reveals that some somatostatin cells (arrows) express IAPP also following dexamethasone treatment, the fraction of cells remaining visibly unchanged as compared with controls. Bar $=100 \mu \mathrm{m}$

high doses of dexamethasone, respectively $(p<0.001$ for both; Fig. 1B, D, F).

Cellular expression of the peptides. When combining ISH with the IAPP probe and immunocytochemistry for IAPP, virtually all cells labelled by the probe were also immunostained (Fig. 2A). There was no difference in this parallelism between the treated group and the controls. Furthermore, in both groups, all insulin cells, as demonstrated by the proinsulin antibody, were labelled by the IAPP probe. Also, a subpopulation of somatostatin immunoreactive cells was labelled by the IAPP probe; the fraction of IAPP-labelled somatostatin cells and the labelling intensity remained visibly unchanged upon dexamethasone treatment (Fig. 2B). No cells immunostained for pancreatic polypeptide or glucagon were labelled by the IAPP probe. When combining ISH with the insu-
Table 2. Pancreatic concentrations of IAPP and insulin after 12 days of daily treatment with saline (controls), dexamethasone $0.2 \mathrm{mg} / \mathrm{kg}$ and dexamethasone $2.0 \mathrm{mg} / \mathrm{kg}$

\begin{tabular}{lll}
\hline & IAPP $(\mathrm{pmol} / \mathrm{g})$ & Insulin $(\mathrm{nmol} / \mathrm{g})$ \\
\hline $\begin{array}{l}\text { Controls } \\
\text { Low dose dexame- }\end{array}$ & $127 \pm 24$ & $4.1 \pm 0.4$ \\
thasone $(0.2 \mathrm{mg} / \mathrm{kg})$ & $236 \pm 45^{\mathrm{a}}$ & $6.1 \pm 0.8^{\mathrm{b}}$ \\
$\begin{array}{l}\text { High dose dexame- } \\
\text { thasone }(2.0 \mathrm{mg} / \mathrm{kg})\end{array}$ & $354 \pm 51^{\mathrm{b}}$ & $6.8 \pm 0.9^{\mathrm{b}}$ \\
\hline
\end{tabular}

There were five animals in each group. Mean \pm SEM are given. ${ }^{\mathrm{a}} p<0.05 ;{ }^{\mathrm{b}} p<0.001$ vs controls

lin probes and immunocytochemistry for proinsulin, virtually all cells labelled by the probes were also immunostained. Most cells labelled by the insulin probes were also immunostained for IAPP in both groups, although a small population of immunostained cells lacked probe-labelling. No labelling with the insulin probes of any other cell type than insulin immunoreactive cells was seen.

Tissue concentration of peptide. The pancreatic concentration of IAPP was increased to $186 \%$ at the low dose of dexamethasone and to $278 \%$ at the high dose of dexamethasone as compared with controls $(p<0.05$ and $p<0.001$, respectively; Table 2$)$. The concentration of insulin was increased to $149 \%$ and $165 \%$ of controls by the low and high doses of dexamethasone, respectively ( $p<0.001$ for both; Table 2). The relative increase of IAPP concentration was significantly greater than that of insulin $(p<0.05)$.

Morphometry. Even at the low dose of dexamethasone, the typical rounded shape of islets was altered in a substantial number of islets. Many islets appeared elongated and lobulated, often displaying irregular borders to the exocrine parenchyma. These changes were even more pronounced at the high dose of dexamethasone (Fig.2A). At the low dose of dexamethasone, the mean area of cells labelled by the insulin probes increased to $267 \pm 10 \%$ of controls $(p<0.001)$, whereas at the high dose of dexamethasone, the mean area of cells labelled by the insulin probes increased to $357 \pm 8 \%$ of controls $(p<0.001$; Table 3).

At the high dose of dexamethasone, the number of proinsulin-immunoreactive cells per islet increased to $247 \pm 12 \%$ of controls ( $p<0.0001$; Table 3 ). 
Table 3. Morphometric analysis of changes in pancreatic islets following dexamethasone treatment

\begin{tabular}{lcc}
\hline & $\begin{array}{l}\text { Number of } \\
\text { insulin cells }\end{array}$ & $\begin{array}{l}\text { Area of probe } \\
\text { labelled insulin } \\
\text { cells }\left(\mu \mathrm{m}^{2}\right)\end{array}$ \\
\hline Controls & $82 \pm 14$ & $13078 \pm 1108$ \\
$\begin{array}{l}\text { Dexamethasone } \\
(0.2 \mathrm{mg} / \mathrm{kg})\end{array}$ & - & $34966 \pm 3590$ \\
$\begin{array}{l}\text { Dexamethasone } \\
(2.0 \mathrm{mg} / \mathrm{kg})\end{array}$ & $202 \pm 25$ & $(267 \pm 10 \%)^{\mathrm{a}}$ \\
\hline
\end{tabular}

The insulin cell number per islet was attained by counting nucleated proinsulin-immunoreactive cells; the area of the cells labelled for the insulin mRNA was attained by manual delineation of the labelled area in islets, using an interactive computerized image analysis system. Mean \pm SEM are given; percentage of controls within parentheses. ${ }^{a} p<0.001$; ${ }^{\mathrm{b}} p<0.0001$ vs controls, respectively

\section{Discussion}

In the present study, we examined the effects of dexamethasone on the expression of IAPP and insulin in islets as well as on the islet morphology and cell number. Our results confirm the previous observations that IAPP and insulin gene expression are regulated in a non-parallel fashion following dexamethasone treatment $[11,13]$. However, while the previous studies used techniques yielding data from the entire pancreas, our approach, using ISH and immunocytochemistry, enabled us to evaluate the cellular changes in islet gene expression and morphology. Thus, alterations in the levels of IAPP and insulin mRNA were quantified and the relative changes for the mRNAs were compared.

At the low dose of dexamethasone $(0.2 \mathrm{mg} / \mathrm{kg})$, the islet levels of IAPP and insulin mRNA were increased to $249 \pm 13 \%$ and $150 \pm 24 \%$ of controls, respectively. The increase in the islet level of IAPP mRNA is due to hyperplasia/hypertrophy of insulin cells, since the cellular level of IAPP mRNA was unaffected while the area of insulin cells increased. Also, the increase in the islet level of insulin mRNA is due to hyperplasia/hypertrophy of insulin cells. In contrast, however, the cellular level of insulin mRNA was actually reduced to $59 \pm 15 \%$ of controls. At the high dose of dexamethasone $(2.0 \mathrm{mg} /$ $\mathrm{kg}$ ), the islet level of IAPP mRNA was increased to $490 \pm 13 \%$ of controls. We consider this increase to be due not only to a hyperplasia/hypertrophy of insulin cells but also to an increased cellular level of IAPP mRNA, since this was increased to $148 \pm 6 \%$ of controls. The high dose of dexamethasone increased the islet level of insulin mRNA to $203 \pm 9 \%$ of controls; this increase, however, is fully explained by the hyperplasia/hypertrophy of the insulin cells, since the cellular level of insulin mRNA was actually reduced to $55 \pm 8 \%$ of controls. Thus, our results suggest that IAPP gene expression is increased at the cellular le- vel at the high dose of dexamethasone, whereas insulin gene expression is reduced at both doses of dexamethasone. This assumption is supported by reports showing that dexamethasone can decrease insulin gene expression in vitro [23, 24].

Previously, it has been shown that the levels of insulin mRNA are increased approximately twofold in pancreatic extracts upon treatment of rats with dexamethasone $0.125-0.25 \mathrm{mg} / \mathrm{kg}$ daily for 4 days $[25,26]$. These doses and the duration of treatment were chosen to avoid hyperplasia/hypertrophy of insulin cells, which is an adaptation of the islets to the high levels of glucocorticoids. Interestingly, in these experiments, the ratio of IAPP/insulin mRNA was unaffected [26]. Therefore, it appears that the divergence of IAPP and insulin gene expression occurs when the insulin cells proliferate and grow under the influence of the high dose of dexamethasone. This suggests that the increase in insulin gene expression that we and others $[11,13,25,26]$ observe is due to a hyperplasia/hypertrophy of the insulin cells, while actually decreasing in the insulin cell. At the high dose of dexamethasone, we observed an increase to $357 \%$ of controls in area of labelled insulin cells and an increase to $241 \%$ in number of insulin cells, indicating both hypertrophy and hyperplasia of the insulin cells. These observations confirm previous data on the effects of glucocorticoids on islet growth and cell proliferation [cf 14, 15, 27, 28]. Our data on the cellular localization of IAPP mRNA indicate that the expression of IAPP in insulin cells, rather than the expression in non-insulin cells, accounts for the observed changes in IAPP gene expression following dexamethasone treatment.

What is the implication of the over-expression of IAPP relative to that of insulin in an insulin-resistant state induced by dexamethasone? Steiner et al. [29] have proposed that IAPP mRNA is less efficiently translated than insulin mRNA, since the biosynthetic rate of IAPP is 100 times lower than that of insulin. Nevertheless, in our study, at the high dose of dexamethasone, we observed an almost threefold greater increase in pancreatic concentration of IAPP than of insulin. Furthermore, IAPP has previously been shown to be hypersecreted relative to insulin in rats following dexamethasone treatment $[12,13]$. These observations, taken together, indicate that the increased level of IAPP mRNA following dexamethasone treatment is matched by an increase in peptide synthesis, revealed as an increased storage and secretion of IAPP. The over-expression of IAPP relative to that of insulin in an insulin-resistant state may therefore be of pathophysiological relevance in NIDDM. Firstly, IAPP may inhibit insulin secretion in a paracrine/autocrine mode. An increased secretion of IAPP may contribute to the impaired insulin secretion, typical of fully developed NIDDM. IAPP tonally inhibits insulin secretion in vivo in rats [30]. 
In transgenic mice over-expressing human IAPP, insulin secretion appears to be unaffected [31] or even increased in vitro [32]. Secondly, an increased local concentration of IAPP in islets, as a consequence of an increased production, may contribute to islet amyloid formation seen in NIDDM [3, 4]. Interestingly, amyloid fibrils formed by human IAPP were recently shown to be cytotoxic for insulin cells in vitro [33]. Thirdly, an increased secretion of IAPP has been suggested to cause peripheral insulin resistance, since exogenously administered IAPP, albeit at pharmacological levels, inhibits glycogen synthesis in rat skeletal muscle in vitro and in vivo [6,7]. However, an IAPPselective antagonist has recently been shown to suppress the rise in plasma lactate seen after intravenous glucose administration [34], suggesting that endogenous IAPP may have effects on glucose homeostasis. Collectively, these observations together with our present data render IAPP a continuously intriguing issue in discussions on the pathogenesis of NIDDM.

Acknowledgements. This study was supported by the Swedish Medical Research Council (Project no. 12X-4499, no. 14X6834 and no. 12X-712), the Swedish Diabetes Association, the Novo Nordic, Albert Påhlsson, Wiberg and Crafoord Foundations and by the Faculty of Medicine, University of Lund. We thank R. Mårtensson, Department of Medical Cell Research, for computing macros for IBAS.

\section{References}

1. Westermark P, Wernstedt C, Wilander E, Sletten K (1986) A novel peptide in the calcitonin gene-related peptide family as an amyloid protein fibril in the endocrine pancreas. Biochem Biophys Res Commun 140: 827-831

2. Cooper GJS, Willis AC, Clark A, Turner RC, Sim RB, Reid KBM (1987) Purification and characterization of a peptide from amyloid-rich pancreases of type 2 diabetic patients. Proc Natl Acad Sci USA 84: 8628-8632

3. Johnson KH, O'Brien TD, Hayden DW et al. (1988) Immunolocalization of islet amyloid polypeptide (IAPP) in pancreatic $\beta$-cells by means of peroxidase-antiperoxidase (PAP) and protein A-gold techniques. Am J Path 130: 1-8

4. Westermark P, Wernstedt C, Wilander E, Hayden DW, O'Brien TD, Johnson KH (1987) Amyloid fibrils in human insulinoma and islets of Langerhans of the diabetic cat are derived from a neuropeptide-like protein also present in normal islet cells. Proc Natl Acad Sci USA 84: 8628-8632

5. Westermark P, Johnson KH, O'Brien TD, Betsholz C (1992) Islet amyloid polypeptide - a novel controversy in diabetes research. Diabetologia 35: 297-303

6. Leighton B, Cooper GJS (1988) Pancreatic amylin and calcitonin gene-related peptide cause resistance to insulin in skeletal muscle in vitro. Nature 335: 632-635

7. Frontoni S, Choi SB, Banduch D, Rossetti L (1990) In vivo insulin resistance induced by amylin primarily through inhibition of insulin-stimulated glycogen synthesis in skeletal muscle. Diabetes 40: 568-573

8. Koopmans SJ, van Mansfeld ADM, Jansz HS et al. (1991) Amylin-induced in vivo insulin resistance in conscious rats: the liver is more sensitive to amylin than peripheral tissues. Diabetologia 34: 218-224

9. Wang ZL, Bennet WM, Ghatei MA, Byfield PGH, Smith DM, Bloom SR (1993) Influence of islet amyloid polypeptide and the 8-37 fragment of islet amyloid polypeptide on insulin release from perifused rat islets. Diabetes 42: 330 335

10. Dégano P, Silvestre RA, Salas M, Peiro E, Marco J (1993) Amylin inhibits glucose-induced insulin secretion in a dose-dependent manner. Study in the perfused rat pancreas. Regul Pept 43: 91-96

11. Bretherton-Watt D, Ghatei MA, Bloom SR et al. (1989) Altered islet amyloid polypeptide (amylin) gene expression in rat models of diabetes. Diabetologia 32: 881-883

12. O'Brien TD, Westermark P, Johnson KH (1991) Islet amyloid polypeptide and insulin secretion from isolated perfused pancreas of fed, fasted, glucose-treated, and dexamethasone-treated rats. Diabetes 40: 1701-1706

13. Pieber TR, Stein DT, Ogawa A et al. (1993) Amylin-insulin relationships in insulin resistance with and without diabetic hyperglycaemia. Am J Physiol 265: E446-E453

14. Lazarus SS, Volk BW (1962) The Pancreas in Human and Experimental Diabetes, 1st edn., Grune \& Stratton, New York

15. Swenne I (1992) Pancreatic beta-cell growth and diabetes. Diabetologia 35:193-201

16. Ahrén B, Sundler F (1992) Localization of calcitonin generelated peptide and islet amyloid polypeptide in the rat and mouse pancreas. Cell Tissue Res 289: 315-322

17. Mulder H, Lindh A-C, Sundler F (1993) Islet amyloid polypeptide gene expression in the endocrine pancreas of the rat. A combined in situ hybridization and immunocytochemical study. Cell Tissue Res 274: 467-474

18. Leffert JD, Newgard CB, Okamoto H, Milburn JL, Luskey KL (1989) Rat amylin: cloning and tissue-specific expression in pancreatic islets. Proc Natl Acad Sci USA 86: 3127-3130

19. Amara SG, Evans RM, Rosenfeld MG (1984) Calcitonin/ calcitonin gene-related peptide transcription unit: tissuespecific expression involves selective use of alternative polyadenylation sites. Mol Cell Biol 4: 2151-2160

20. Lomedico P, Rosenthal N, Efstratiadis A, Gilbert W, Kolodner R, Tizard R (1979) The structure and evolution of the two nonallelic rat preproinsulin genes. Cell 18: 545558

21. Morgan CR, Lazarow A (1963) Immunoassay of insulin. Two antibody system: plasma insulin levels of normal, subdiabetic and diabetic rats. Diabetes 12: 115-126

22. Stridsberg M, Wilander E, Öberg K, Lundqvist G, Eriksson B (1992) Islet amyloid polypeptide-producing pancreatic islet cell tumor. A clinical and biochemical characterization. Scand J Gastroenterol 27: 381-387

23. Philippe J, Missotten M (1990) Dexamethasone inhibits insulin biosynthesis by destabilizing insulin messenger ribonucleic acid in hamster insulinoma cells. Endocrinology 127: $1640-1645$

24. Fernandez-Meija C, Goodman P, Davidson M (1993) Hormonal regulation of human insulin gene transcription. Diabetes 42: [Suppl 1]731

25. Giddings SJ, Orland MJ, Weir GC, Bonner-Weir S, Permutt MA (1985) Impaired insulin biosynthetic capacity in a rat model for non-insulin-dependent diabetes. Studies with dexamethasone. Diabetes 34: 235-240

26. Koranyi L, Bourey R, Turk J, Mueckler M, Permutt MA (1992) Differential expression of rat pancreatic islet betacell glucose transporter (Glut 2), proinsulin and islet amyloid polypeptide genes after prolonged fasting, insulin-in- 
duced hypoglycaemia and dexamethasone treatment. Diabetologia 35: 1125-1132

27. Like AA, Chick WL (1974) Pancreatic beta cell replication induced by glucocorticoids in subhuman primates. Am J Pathol 75: 329-348

28. Bonner-Weir S, Trent DF, Zmachinski CJ, Clore ET, Weir GC (1981) Limited B cell regeneration in a B cell deficient rat model: studies with dexamethasone. Metabolism 30: 914-918

29. Steiner DF, Ohagi S, Nagamatsu S, Bell GI, Nishi M (1991) Is islet amyloid polypeptide a significant factor in the pathogenesis or pathophysiology of diabetes? Diabetes 40: 305-309

30. Bennet WM, Beis CS, Ghatei MA, Byfield PGH, Bloom SR (1994) Amylin tonally regulates arginine-stimulated insulin secretion in rats. Diabetologia 37: 436-438
31. Fox N, Schrementi J, Nishi M et al. (1993) Human islet amyloid polypeptide transgenic mice as a model of non-insulin-dependent diabetes mellitus (NIDDM). FEBS Lett 323: 40-44

32. Verchere CB, D'Alessio DAD, Palmiter RD, Kahn SE (1994) Transgenic mice overproducing islet amyloid polypeptide have increased insulin storage and secretion in vitro. Diabetologia 37: 725-728

33. Lorenzo A, Razzaboni B, Weir GC, Yankner BA (1994) Pancreatic islet cell toxicity of amylin associated with type-2 diabetes mellitus. Nature 368: 756-760

34. Young AA, Gedulin B, Gaeta LSL et al. (1994) Selective amylin antagonist suppresses rise in plasma lactate seen after intravenous glucose in the rat. Evidence for a metabolic role of endogenous amylin. FEBS Lett 343: 237-241 